\title{
Pengembangan Bahan Ajar Bahasa Indonesia dengan Menggunakan Model Shared Di SD Karuwisi II Kota Makassar
}

\section{Development of Indonesian Language Teaching Materials Using the Shared Model at SD Karuwisi II Makassar City}

\author{
Sitti Khadijah'1, Asdar², A. Hamsiah² \\ ${ }^{1}$ Magister Pendidikan Dasar Program Pascasarjana, Universitas Bosowa \\ 2Program Studi Studi Pendidikan Dasar, Program Pascasarjana, Universitas Bosowa \\ E-mail: sitikhadijah1293@gmail.com
}

Diterima: 14Juli 2020/Disetujui 07 Desember 2020

\begin{abstract}
Abstrak. Tujuan dari penelitian ini adalah mengetahui dan menganalisis kevalidan kepraktisan dan keefektifan Bahan Ajar Bahasa Indonesia dengan Mengunakan Model Shared di SD Karuwisi II Kota Makassar. Peneltian ini adalah penelitian pengembangan. Penelitian ini mengembangkan perangkat yang akan membantu siswa dalam memahami pembelajaran terpadu, khususnya tipe shared. Penelitian Ini dilakukan di SD Karuwisi II Kota Makassar. Subjek penelitian ini adalah siswa kelas IV SD Karuwisi II Kota Makassar. Teknik pengumpulan data dalam penelitian ini menggunakan observasi and angket. Peneliti menganalisis data secara kualitatif dan kuantitatif. Penelitian menghasilkan produk prototipe model bahan ajar bahasa Indonesia dengan model shared. Hasil uji coba model bahan ajar baik pada uji coba terbatas maupun uji coba lapangan menunjukkan bahwa bahan ajar bahasa Indonesia dengan model shared layak untuk digunakan. Dengan demikian, dapat disimpulkan bahwa bahan ajar bahasa Indonesia dengan model shared yang terdiri dari buku bahan ajar bahasa Indonesia beserta panduan penggunaannya, dan buku lembar kerja siswa (LKS) dinyatakan valid, praktis, efektif dan layak digunakan.
\end{abstract}

Kata Kunci: Bahan Ajar, Model Shared, Pengembangan, SD, Makassar

\begin{abstract}
The aim of this study was to find out and analyze the validity, practicality and effectiveness of Indonesian Language Teaching Materials by Using the Shared Model at Karuwisi II Elementary School, Makassar. This study is development research. This research develops teaching materials that help students to understand integrated learning, especially the Shared Model. This research was conducted at Karuwisi II Elementary School, Makassar. The subject of this study was fourth grade students of SD Karuwisi II, Makassar. Data collection techniques in this study used observation and questionnaires. The researcher analyzed the data qualitatively and quantitatively. This study produced a prototype model of Indonesian language teaching materials with the Shared Model. The results of the trial of teaching material models both in limited trials and field trials indicated that Indonesian language teaching materials with the Shared Model were feasible to use. Thus, it can be concluded that the Indonesian language teaching materials with the Shared Model consisting of Indonesian language teaching materials along with guidelines for their use and student worksheets were valid, practical, effective and appropriate to use.
\end{abstract}

Keywords: Teaching materials, Shared Model, Elementary School, Makassar

\section{Pendahuluan}

UU No. 20 Tahun 2003 tentang SISDIKNAS, yakni: Untuk mengatahui defenisipendidikan dalam perspektif kebijakan, kita telah memiliki rumusan formal dan operasional, sebagaimana, Pendidikan adalah usaha sadar dan terencana untuk kepribadian, kecerdasan, akhlak mulia, serta keterampilan yang diperlukan dirinya, masyarakat, Bangsa dan Negara.

Bahan pembelajaran dalam konteks pembelajaran merupakan salah satu komponen yang harus ada, karena bahan pembelajran merupakan suatu komponen yang harus dikaji, dicermati, dipelajari dan dijadikan bahan materi yang akan dikuasai oleh siswa dan sekaligus dapat memberikan pedoman untuk mempelajarinya. Tanpa bahan pembelajaran maka pembelajaran tidak akan menghasilkan apa-apa (Jainuddin, 2019). Bahan ajar merupakan komponen penting dalam pembelajaran. Bahan ajar yang disampaikan seorang guru hendaknya mengacu kepada tujuan yang telah digariskan dalam kurikulum. Oleh karena itu, guru mempunyai keleluasaan untuk mengembangkan bahan ajar yang akan disampaikan sejauh tidak menyimpang dari tujuan (Jainuddin et al, 2020).

Pengembangan bahan ajar erat kaitannya dengan sumber acuan yang digunakan. Banyak sumber bahan ajar yang dapat digunakan, tetapi hendaknya dipilih yang sesuai dengan kondisi pembelajaran. Di samping itu, dalam menyampaian bahan ajar hendaknya dipilih pula metode apa yang dapat dijadikan sarana untuk menyampaian bahan ajar secara efektif. Keefektifan penyampaian bahan ajar juga didukung oleh media yang digunakan. Selain itu, evaluasi mempunyai peran penting dalam rangka masukan untuk mengadakan perbaikan-perbaikan bahan ajar yang akan dikembangkan. Hal-hal yang 
perlu diperhatikan dalam pengembangan bahan ajar tentu saja banyak ragamnya, tetapi yang terpenting adalah pola pengembangan yang mengacu kepada tujuan pembelajaran. Oleh karena itu, faktor guru memegang peranan penting dalam penembangan bahan ajar. Gurulah yang harus berinisiatif untuk selalu mengadakan perbaikan-perbaikan yang berkenaan dengan pembelajaran.

Model pembelajaran shared atau model berbagi merupakan model belajar mengajar yang didasarkan pada gabungan pemikiran yang muncul dari beberapa disiplin ilmu. Proses belajar mengajar dalam mata pelajaran yang akan dipadukan melelui banyak cara dan metode, salah satunya adalah metode pembelajaran terpadu model shared. Dengan adanya pembelajaram model shared siswa lebih aktif, kreatif dan materi yang disampaikan lebih bermakna

Model shared merupakan pembelajaran terpadu yang menggabungkan dua mata pelajaran dengan konsep, sikap, dan keterampilan yang sama dan berada di dalam ruang lingkup mata pelajaran maka model ini akan menjadi awal untuk menggabungkan mata pelajaran bahasa Indonesia. Model shared juga memiliki kekurangan, kelebihan dan ciri-cirinya yang akan dibahas lebih dalam pada tesis ini. Berdasarkan uraian tersebut, peneliti akan melakukan sebuah penelitian yang bertujuan untuk Pengembangan Bahan Ajar dengan mengunakanmodel Shared di SD KarawisiII Kota Makassar.

Tujuan penelitian ini adalah Untuk mengetahui kevalidan dan bahan ajar bahasa Indonesia dengan menggunakan model shared di SD Karawisi II Kota Makassar, Untuk mengetahui kepraktisan bahan ajar bahasa Indonesia dengan menggunakan model shared di SD Karawisi II Kota Makassar, Untuk mengetahui keefektifan bahan ajar bahasa Indonesia dengan menggunakan model shared di SD Karawisi II Kota Makassar.

Widodo dan Jasmadi dalam Lestari (2013) menyatakan bahwa bahan ajar adalah seperangkat sarana atau alat pembelajaran yang berisikan materi pembelajaran, metode, batasan-batasan, dan cara mengevaluasi yang didesain secara sistematis dan menarik dalam rangka mencapai tujuan yang diharapkan, yaitu mencapai kompetensi dan subkompetensi dengan segala kompleksitasnya.

Pengembangan suatu bahan ajar harus didasarkan pada analisis kebutuhan siswa. Terdapat sejumlah alasan mengapa perlu dilakukan pengembangan bahan ajar, seperti yang disebutkan oleh Direktorat Pembinaan Sekolah Menengah Atas (2008) sebagai berikut. Ketersediaan bahan sesuai tuntutan kurikulum, artinya bahan belajar yang dikembangkan harus sesuai dengan kurikulum.

Secara umum bahan ajar dapat dibedakan ke dalam bahan ajar cetak dan noncetak. Bahan ajar cetak dapat berupa, handout, buku, modul, brosur, dan lembar kerja siswa. Sedangkan bahan ajar noncetak meliputi, bahan ajar audio seperti, kaset, radio, piringan hitam, dan compact disc audio. Bahan ajar audio visual seperti, CAI (Computer Assisted Instruction), dan bahan ajar berbasis web (web based learning materials) (Ika Lestari, 2013).

Rudi Susilana (2008) mengungkapkan bahwa buku teks adalah buku tentang suatu bidang studi atau ilmu tertentu yang disusun untuk memudahkan para guru dan siswa dalam upaya mencapai tujuan pembelajaran.

Menurut Asdar (2017), dalam proses pendidikan dan pembelajaran bahasa Indonesia di perguruan tinggi, mahasiswa diarahkan untuk memiliki keterampilan berbahasa Indonesia. Bahasa harus dilihat sebagai satu kesatuan dan diajarkan secara terintegrasi sehingga dibutuhkan pendekatan integratif. Sejalan dengan pendapat tersebut pendekatan integratif dapat dikembangkan dengan memadukan aspek-aspek keterampilan berbahasa pada sekolah dasar sehingga proses belajar mengajar lebih terarah dan terintegrasi dengan baik.

Menurut Pratiwi (2013) model shared adalah suatu pendekatan belajar mengajar yang menggabungkan dua mata pelajaran dengan melihat konsep, sikap dan ketrampilan yang sama. Penggabungan antara konsep pelajaran, keterampilan dan sikap yang saling berhubungan satu dengan yang lainnya dipayungi dalam satu tema, sehingga dapat memberikan pengalaman belajar yang bermakna bagi siswa. Menurut Pratiwi (2013) model shared adalah suatu pendekatan belajar mengajar yang menggabungkan dua mata pelajaran dengan melihat konsep, sikap dan ketrampilan yang sama. Penggabungan antara konsep pelajaran, keterampilan dan sikap yang saling berhubungan satu dengan yang lainnya dipayungi dalam satu tema, sehingga dapat memberikan pengalaman belajar yang bermakna bagi siswa.

Pembelajaran terpadu model berbagi shared dapat diterapkan pada tingkat SD sebagai alternative pembelajaran. Hal ini dimungkinkan karena peran guru di tingkat SD merupakan guru kelas, yang dapat mengatur sendiri cara menyajikan beberapa pelajaran disesuaikan dengan keterbatasan alat pelajaran, waktu, bahan ajar dan kondisi kemampuan sisiwa. Guru dapat memilih mata pelajaran yang memiliki tema yang sesuai dan dapat dipadukan. Tidak semua mata pelajaran dapat dipadukan, karena guru kelas harus melakukan perencanaan yang matang dalam melaksanakan pembelajaran model berbagi.

Pelaksanaan pembelajaran terpadu bertolak pada topik tertentu yang dikembangkan oleh guru dan siswa, yang dilengkapi dengan alat peraga dan lembar kerja siswa (LKS). Sedangkan tujuan pembelajaran dapat tercapai. Dalam pembelajaran terpadu, model berbagi ini berorientasi pada siswa dengan variasi sehingga kegiatan terpadu model shared mencakup ranah kognitif, afektif dan psikomotor yang mentujukan pada pemahaman dan pengembangan konsep, sikap, dan ketrampilan agar lebih bermakna dalam kegiatan evaluasi digunakan lingkungan sebagai sumber belajar.

Proses pengembangan pembelajaran terpadu model shared meliputi:

1. Menganalisis GBPP dari setiap mata pelajaran yang akan dipadukan misalnya Bahasa Indonesia Membaca dengan Menulis.

2. Menentukan konsep, keterampilan dan sikap terhadap mata pelajaran yang dipilih.

3. Mengalokasikan waktu dengan benar sesuai dengan konsep yang akan disampaikan.

4. Kegiatan pembelajaran disesuaikan dengan perkembangan anak dengan menggunakan lingkungan sehingga segala sesuatu yang terjadi di masyarakat yang akhirnya pembelajaran terpadu bermanfaat bagi kehidupan siswa sehari-hari.

\section{Langkah-langkah model shared}

a. Guru menentukan dua disiplin ilmu yang dapat difokuskaan pada konsep, sikap, dan keterampilan yang sama. 
b. Guru menentukan tema dari dua disiplin ilmu yang telah dipilih.

c. Guru memilih konsep, kegiatan atau informasi yang dapat mendorong belajar siswa untuk memberikan pengalaman bagi siswa tersebut.

Rancangan Pengembangan Bahan Ajar Model Dick And Carrey

Adapun pendekatan model Dick dan Cerey dapat dijelaskan sebagai berikut:

1. Identifikasi tujuan

2. Melakukan analisis instruksional.

3. Mengidentifikasi tingkah laku awal dan karakteristik pebelajar

4. Merumuskan Tujuan Kinerja.

5. Pengembangan tes acuan patokan.

6. Pengembangan Strategi Pengajaran.

7. Pengembangan atau memilih pengajaran.

8. Merancang dan melaksanakan evaluasi formatif.

9. Revisi pengajaran

10. Mengembangkan evaluasi sumatif

Tujuan penelitian adalah mengetahui dan menganalisis kevalidan kepraktisan dan keefektifan Bahan Ajar Bahasa Indonesia dengan Mengunakan Model Shared di SD Karuwisi II Kota Makassar.

\section{Metode Penelitian}

Peneltian ini adalah penelitian pengembangan (Research and Development) Sugiyono (2014) menjelaskan Research and Development "metode penelitian yang digunakan untuk menghasilkan produk tertentu dan menguji kefektifan produk tertentu" Penelitian ini mengembangkan perangkat yang akan membantu siswa dalam memahami pembelajaran terpadu, khususnya tipe shared. Borg dan Gall (dalam Sugiyono, 2012) menguraikan langkah-langkah dalam penelitian pengembangan yaitu:

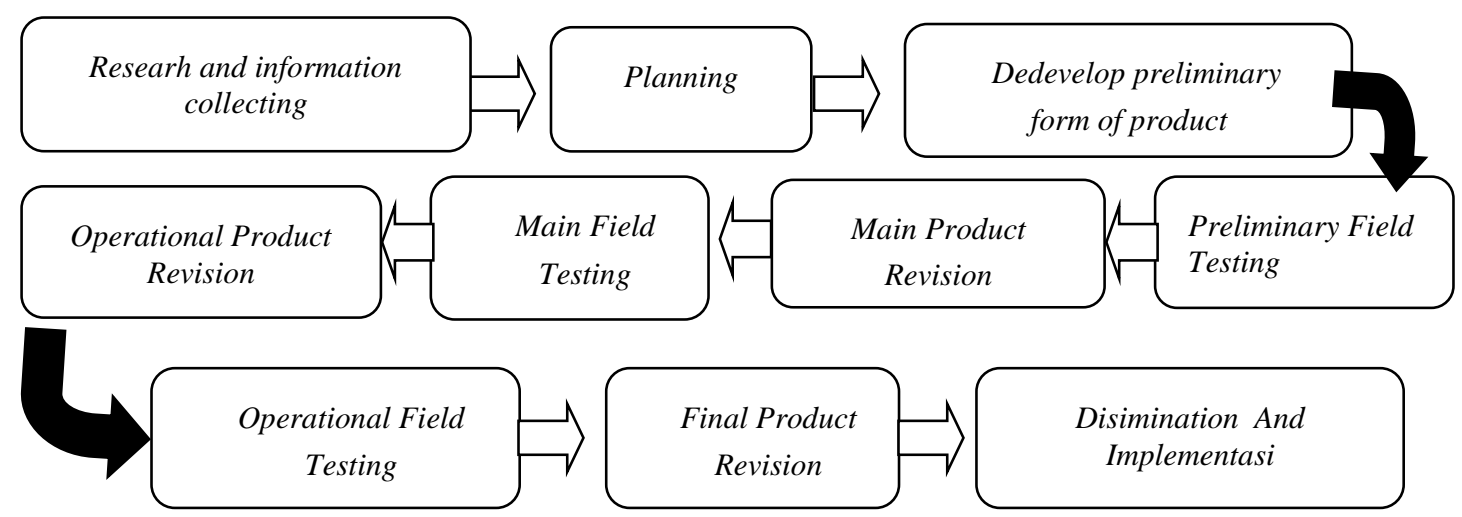

Gambar 1 Langkah penelitian dan pengembangan menurut Brog dan Gall

Penelitian Ini dilakukan di SD Karuwisi II Kota Makassar yang terletak di Jalan Urip Sumoharjo, Kecamatan Panakukang, Kota Makassar. Waktu penelitian dilaksanakan mulai bulan April hingga Mei 2019 Subjek penelitian ini adalah siswa kelas IV SD Karuwisi II Kota Makassar tahun ajaran 2019/2020 yang berjumlah 25 orang siswa pada mata pelajaran bahasa Indonesia. Teknik Analisis Data Validitas Bahan Ajar menurut Sugiyono (2015) menyatakan bahwa jika sebuah instrumen dinilai atau divalidasi oleh beberapa ahli (tiga orang atau lebih), maka kesimpulan ditarik berdasarkan dominasi penelitian (expert).

\section{Hasil dan Pembahasan}

\section{Analisis Kebutuhan Siswa dan Guru}

Guru dan siswa adalah objek sasaran yang akan menggunakan model bahan ajar ini. Oleh karena itu, terlebih dahulu harus diketahui indikator model bahan ajar yang mereka kehendaki. Untuk mengetahui kebutuhan guru dan siswa terhadap model bahan ajar peneliti memberikan tes dengan sesuai dengan bahan ajar yaitu membaca dan menulis. Adapun data yang telah diperoleh melalui hasil tes tersebut sebagai berikut. Hasil belajar siswa terhadap indikator model bahan ajar yang dapat dilihat pada Tabel 1 .

Tabel 1 menunjukkan bahwa hasil menulis siswa kelas 4 SDN Karuwisi II Makassar. Diketahui bahwa terdapat 11 $(52.4 \%)$ siswa dikategorikan baik, 5 (23.8\%) siswa dikategorikan sedang, dan $5(23.8 \%)$ siswa dikategorikan kurang. Hasik penelitian ini juga menunjukkan bahwa tidak ada siswa yang dikategorikan sangat baik dan kurang baik. Penelitian ini difokuskan pada siswa kelas 4 SDN Karuwisi II Makassar. Menurut responden (guru), rata-rata siswa menguasai materi belajar yang diberikan. Berkaitan dengan itu, dua kompetensi atau keterampilan berbahasa yang diharapkan dimiliki oleh 
siswa juga sangat baik. Sebagai contoh, siswa sangat baik dalam hal tata tulis dan ejaan yang baik, ditambah lagi kemampuan membacanya.

Tabel 1 Hasil Belajar Siswa

\begin{tabular}{|c|c|c|c|}
\hline Rentang Nilai & Klasifikasi & $\mathrm{F}$ & $\%$ \\
\hline $91-100$ & Sangat Baik & - & - \\
\hline $76-90$ & Baik & 11 & 52.4 \\
\hline $61-75$ & Sedang & 5 & 23.8 \\
\hline $51-60$ & Kurang & 5 & 23.8 \\
\hline$<50$ & Kurang Baik & - & - \\
\hline \multicolumn{2}{|c|}{ Jumlah } & 21 & 100 \\
\hline
\end{tabular}

Sumber: SDN Karuwisi II Makassar (2019)

Setelah melalui tahap perancangan, model bahan ajar pun dikembangkan menjadi sebuah prototipe (konsep awal), yakni model bahan ajar yang harus diuji kelayakannya. Untuk memvalidasi bahan ajar, setiap validator diberikan draf model bahan ajar yang dikembangkan bersama lembar validasi. Validasi model bahan ajar dilakukan sampai hasil evaluasi dinyatakan valid. Adapun hasil validasi tersebut sebagai berikut:

Hasil Uji Validasi Ahli Materi

Adapun hasil uji validasi adalah sebagai berikut:

Tabel 2. Rangkuman Validasi Aspek Isi/Materi Bahan Ajar Ahli Materi

\begin{tabular}{llccc}
\hline & \multicolumn{1}{c}{ Indikator } & Rerata & \multicolumn{2}{c}{ Keterangan } \\
\hline A. & Kesesuaian materi dengan SK dan KD & 4 & Valid \\
B. & Keakuratan materi & 4.2 & Valid \\
C. & Pendukung Materi Pembelajaran & 3.8 & Valid \\
D. & Kemutakhiran Materi & 4.3 & Valid \\
\hline \multicolumn{2}{r}{} & Rerata & 4.1 & Valid \\
\hline
\end{tabular}

Sumber: Analisa Data, 2019

Setelah dilakukan revisi terhadap kekurangan dan kelemahan bahan ajar, hasil uji validasi menunjukkan perkembangan yang signifikan. Uji validasi seperti yang tergambar pada tabel di atas menunjukkan bahwa semua indikator aspek isi atau materi bahan ajar dinyatakan valid. Rangkuman hasil validasi aspek tata penyajian seperti pada tabel berikut ini.

Tabel 3. Rangkuman Validasi Tata Penyajian Model Bahan Ajar Ahli Materi

\begin{tabular}{ccc}
\hline Indikator & Rerata & Keterangan \\
Teknik penyajian & 4,00 & Valid \\
Pendukung penyajian & 4,00 & Valid \\
Penyajian pembelajaran & 4,00 & Valid \\
Kelengkapan penyajian & 4,50 & Valid \\
\hline Rerata & 4.13 & Valid \\
\hline
\end{tabular}

Sumber: Analisa Data, 2019

Tabel 3 di atas menunjukkan bahwa keempat aspek tata penyajian model bahan ajar dinyatakan valid pada uji validasi. Rerata total keempat aspek tersebut adalah 4.13 dan dinyatakan valid, dengan indikator sebagai berikut; (1) teknik penyajian memiliki nilai 4,00, (2) pendukung penyajian memiliki nilai 4,00, (3) penyajian pembelajaran memiliki nilai 4,00, (4) kelengkapan penyajian r memiliki nilai 4,50. Jadi, total reratta secara keseluruhan keempat aspek tersebut adalah 4,13.

Hasil Uji Validasi Ahli Media

Uji validitas oleh ahli media adalah uji yang dilakukan setelah dilakukan revisi kekurangan hasil validasi. Aspek tata grafis dan kebahasaan model bahan ajar pada uji validitas telah dinyatakan valid dan layak untuk digunakan. Adapun hasil uji validasi aspek tata grafis bahan ajar oleh ahli media menunjukkan hasil yang baik.

Jadi, jika dicermati hasil uji bahan ajar bahasa Indonesia dengan model Shared pada aspek tata grafis oleh ahli media telah dinyatakan valid. Rerata nilai masing-masing indikator mengalami peningkatan yang signifikan. Bentuk bahan ajar telah dinyatakan valid karena rerata nilai telah mencapai 4,25, sehingga tidak divalidasi kembali. Desain isi bahan ajar dinyatakan valid dengan rerata nilai 4.20. Sedangkan indikator desain sampul dinyatakan juga valid dengan rerata nilai adalah 3.90. Rangkuman hasil uji validasi di atas tergambar pada tabel berikut:

Tabel 4. Rangkuman Validasi Aspek Tata Grafis Model Bahan Ajar Ahli Media

\begin{tabular}{lccc}
\hline & Indikator & Rerata & Keterangan \\
\hline Bentuk bahan ajar & & 4,25 & Valid \\
Desain Sampul bahan ajar & & 4.20 & Valid \\
Desain isi bahan ajar & Rerata & 3.90 & Valid \\
\hline
\end{tabular}

Sumber: Analisa Data, 2019

Tabel 4 di atas menunjukkan rerata total keseluruhan indikator yaitu 4,12 dengan predikat valid. Hal ini didukung oleh hasil nilai pada indikator (1) bentuk bahan ajar memiliki nilai 4,25, (2) desain sampul bahan ajar memiliki nilai 4,20, dan desain isi bahan ajar dengan rerata nilai 3,90.. Artinya, jika ditinjau dari segi tata grafis, model bahan ajar bahasa Indonesia dengan model shared telah memenuhi persyaratan untuk digunakan.

Hasil validasi bahan ajar aspek kebahasaan dirangkum dalam tabel berikut. 
Tabel 5. Rangkuman Validasi Aspek Kebahasaan Model Bahan Ajar Ahli Media

\begin{tabular}{llccc}
\hline & & Indikator & Rerata & Keterangan \\
\hline a. & Lugas & 4,50 & Valid \\
b. & Komunikatif & 4,50 & Valid \\
c. & Dialogis dan interaktif & 4,00 & Valid \\
d. & Kesesuaian dengan perkembangan peserta didik & 4,00 & Valid \\
e. & Kesesuaian dengan kaidah bahasa & 3.75 & Valid \\
f. & Penggunaan istilah, simbol, dan ikon & 3.75 & Valid \\
\hline \multicolumn{2}{c}{ Rerata } & 4.08 & Valid \\
\hline
\end{tabular}

Sumber: Analisa Data, 2019

Tabel 5 di atas menunjukkan rerata total keseluruhan indikator yaitu 4.08 dengan predikat valid. Indikator (a) lugas memiliki nilai 4,50 (b) indikator komunikatif memiliki nilai 4,00, (c) indikator dialogis dan interaktif memiliki nilai 4,00, (d) indikator kesesuaian dengan peserta didik memiliki nilai 4,00, (e) indikator kesesuaian dengan kaidah bahasa memiliki nilai 3.75, (f) indikator penggunaan istilah simbol/ikon memiliki nilai 3.75. Artinya, jika ditinjau dari segi kebahasaan, model bahan ajar bahasa Indonesia dengan model shared telah memenuhi persyaratan untuk digunakan..

Sehubungan dengan penelitian pengembangan ini telah diadakan pengembangan model bahan ajar bahasa Indonesia dengan model shared. Proses pengembangan model bahan ajar ini telah melahirkan satu model bahan ajar yang mencakup lima komponen, yaitu (1) bahan ajar, (2) panduan bahan ajar, (3) lembar kerja mahasiswa, (4) panduan penggunaan lembar kerja siswa, dan (5) panduan penilaian lembar kerja siswa. Dalam proses pengembanganmodel bahan ajar bahasa Indonesia dengan model shared ini, model ini telah melalui beberapa perubahan berdasarkan masukan dari validator dan pembimbing. Perubahan yang signifikan dapat dilihat pada beberapa hal berikut ini.

\section{Sampul Model Bahan Ajar}

Pada komponen bahan ajar, perubahan yang terjadi dapat dilihat pada sampul depan. Pada awal konsultasi, desain sampul depan model bahan ajar berlatar hijau. Pemilihan warna berdasarkan inisiatif penulis. Lalu, sampul itu dibubuhi judul bahan ajar bahasa Indonesia dengan model shared nama pengembang model bahan ajar (Sitti Khadijah) seperti tampak pada gambar berikut.

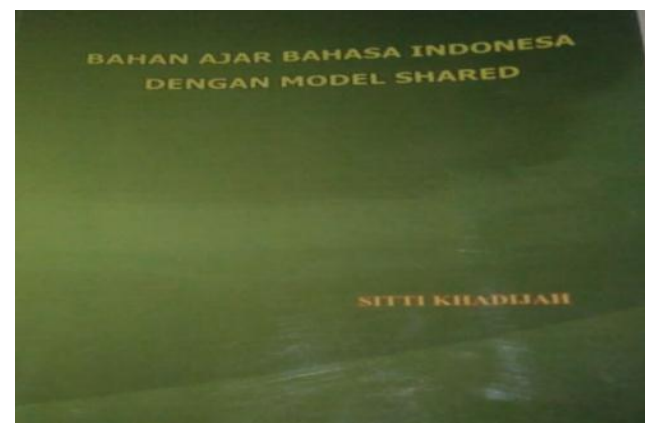

Gambar 2. Desain Sampul Tahap Awal

Adapun sampul depan pengembangan model bahan ajar bahasa Indonesia dengan model shared setelah adanya revisi, yaitu:

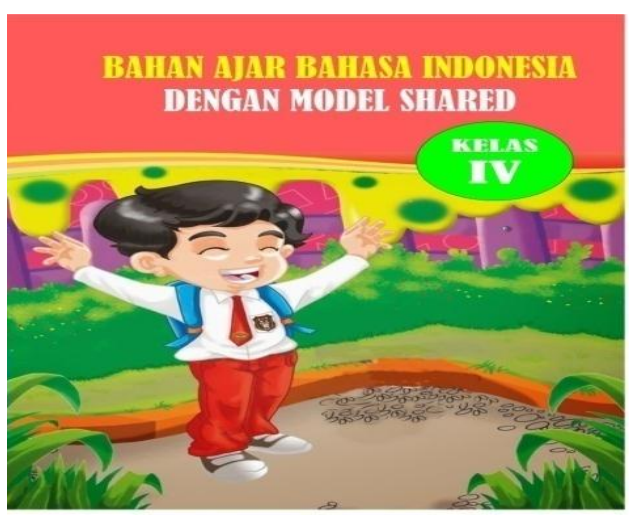

Gambar 3. Desain SampulTahap Akhir

Pada tahap 2, adanya perubahan pada desain sampul depan model bahan ajar berlatar judul bahan ajar bahasa Indonesia dengan model shared berada ditengah dan nama penulis diletakkan pada pojok kiri atas. Pada tahap awal, desain sampul pengembangan bahan ajar menggunakan simbol pena dan pada tahap akhir diganti dengan gambar siswa yang sedang. Selain itu, pada bagian sampul dilengkapi dengan identitas model bahan ajar berupa judul, kelas dan nama pengembang model bahan ajar (Sitti Khadijah).Warna yang beragam tetap dipilih sebagai sampul bahan ajar karena diselaraskan dengan kebutuh minat siswa dan sekolah. 
Setelah rancangan model bahan ajar selesai, langkah selanjutnya adalah memvalidasi model bahan ajar. Validitas model bahan ajar diukur berdasarkan nilai rerata yang diberikan oleh sejumlah validator terhadap model bahan ajar dengan taraf rerata validitas 3,4, dan 5 pada jenjang kategori valid. Jumlah validator yang dipilih untuk memvalidasi model bahan ajar sebanyak 2 orang yaitu bertindak sebagai ahli materi yang menilai isi atau materi model bahan ajar dan tata penyajian model bahan ajar, menilai aspek media yaitu tata grafik dan bahasa model bahan ajar. Hasil validasi menunjukkan bahwa model bahan ajar ini layak diujicobakan setelah melalui dua kali tahap revisi. Validasi model bahan ajar tahap awal masih dijumpai berbagai kelemahan baik dari teknik penyajian, pendukung penyajian, penyajian pembelajaran serta koherensi dan keruntutan alur pikir. Setelah dilakukan revisi dan divalidasi kembali, model-model bahan ajar menulis bahan ajar bahasa Indonesia dengan model shared dinyatakan valid dengan rerata validasi ahli materi pada aspek isi adalah 4,10 dan rerata total aspek tata penyajiannya sebesar 4.13. Sedangkan hasil validasi ahli media menunjukkan rerata total pada aspek kegrafikan model bahan ajar sebesar 4,12 dan aspek kebahasaan sebesar 4,08.

\section{Kesimpulan dan Saran}

Hasil penelitian dapat disimpulkan bahwa siswa dan guru membutuhkan model bahan aj ajar bahasa Indonesia dengan model shared. Informasi tentang kebutuhan itu diperoleh dari hasil uji lapangan kepada siiswa yang dijadikan sumber data penelitian. Setelah dilakukan berbagai prosedur dalam melakukan penelitian pengembangan yang berorientasi pada penelitian menghasilkan produk prototipe model bahan ajar bahasa Indonesia dengan model shared. Penelitian ini menghasilkan prototipe bahan ajar bahasa Indonesia dengan model shared yang terdiri dari buku bahan ajar bahasa Indonesia beserta panduan penggunaannya, buku lembar kerja siswa (LKS) beserta panduan penggunaannya, Hasil penelitian ini dapat disimpulkan bahwa melalui uji validasi dari para pakar, prototipe model bahan ajar bahasa Indonesia dengan model shared ini dinyatakan valid, baik dari segi materi (isi dan penyajian) maupun dari segi media (tatakegrafikan dan kebahasaan), Setelah melalui uji coba lapangan sebanyak 2 kali uji coba, yaitu uji coba lapangan 1 dan 2 , model bahan ajar bahasa Indonesia dengan model shared ini dinyatakan memenuhi syarat kepraktisan, Hasil uji coba model bahan ajar pada uji coba lapangan menunjukkan bahwa bahan ajar bahasa Indonesia dengan model shared sangat efektif dalam meningkatkan hasil belajar siswa pada aspek membaca dan menulis. Efektivitas model bahan ajar diukur dari hasil belajar siswa dan respon guru yang menyatakan bahwa model bahan ajar paneliti berbeda dengan bahan ajar yang digunakan di sekolah. Dengan demikian, model bahan ajar bahasa Indonesia dengan model shared dinyatakan efektif dan layak untuk digunakan.

\section{Daftar Pustaka}

Asdar. 2017. Pengembangan Model Bahan Ajar Menulis Wacana Eksposisi Berbasis pendekatan Integratif Untuk mahasiswa Program Studi Pendidikan Bahasa Indonesia FKIP Universitas Bosowa. Disertasi. Makassar: Universitas Negeri Makassar

Borg \& Gall,2003.Education Research. New York :Allyn and Bacon.

Borg, $\mathrm{W} \quad \mathrm{R} \quad \& \quad$ Gall, $\mathrm{M}$ D. 2005. Educational research: an introduction, Fourth Edition. New York: Longman. Inc http://apjee.usm.my/JPP_17_2001/Jilid\%2017\%20Artikel\%2010.pdf (Diakses 10 April 2019)

Depdiknas. 2008. Kurikulum Tingkat Satuan Pendidikan. Jakarta: Dikmenum. Depdiknas.

Dick. W, Carey. L. Carey. J.O. 2001. The Systematic Design of Instruction. Addison Wesley Educational Publisher Inc.https://www.academia.edu/34825630/Walter_Dick_Lou_Carey_James_O._

Carey_The_Systematic_Design_of_Instruction_Pearson_2015_(Diakses 10 April 2019)

Dick dan Carey. 2009. The Systematic Design of Instruction. New Jersey: Pearson.

Direktorat Pembinaan Sekolah Menengah Atas. 2008. Panduan Pengembangan Bahan Ajar. Jakarta: Departemen Pendidikan Nasional.

Dyah Pratiwi. 2013. Analisis Pengelolaan Limbah Medis Padat Pada Puskesmas Kabupaten Pati. http://lib.unnes.ac.id/18384/1/6450408020.pdf [diakses; Diakses 10 April 2019]

Jainuddin, J., \& Sirajuddin, S. (2020). Pengaruh Minat dan Kedisiplinan Siswa dengan Gaya Kognitif Field Indefendent terhadap Hasil Belajar Matematika Siswa SMK Farmasi Yamasi Makassar. Delta-Pi: Jurnal Matematika dan Pendidikan Matematika, 9(2).

Jainuddin, J. (2019). Peningkatan Hasil Belajar Matematika Melalui Latihan Menyelesaikan Soal Secara Sistematis Pada Siswa Kelas XI. IPA1 SMA Negeri 2 Sungguminasa. Klasikal: Journal Of Education, Language Teaching And Science, 1(3), 44-52.

Lestari Ika. 2013. Pengembangan Bahan Ajar Berbasis Kompetensi. Padang: Akademia Permata

Piaget, Jean, \&BarbelInhelder, 2010. Psikologi Anak, Terj. Miftahul Jannah. Yogyakarta: Pustaka Pelajar Cet. 1,

Rudi Susilana dan Cepi Riyana ,2008.Media Pembelajaran. Bandung :Wacana Prima.

Sugiyono, 2008. Metode Penelitian Kunatitatif Kualitatif dan R\&D. Bandung Alfabeta

Sugiyono, 2009, Metode Penelitian Kuantitatif, Kualitatifdan R\&D,Bandung :Alfabeta.

Sugiyono 2010. MetodePenelitian Kuantitatif Kualitatif \& RND. Bandung :Alfabeta

Sugiyono. 2014. Metode Penelitian Pendidikan Pendekatan Kuantitatif, Kualitatif, dan R\&D. Bandung: Alfabeta.

Susilana, Rudi dan Cepi Riyana. 2007. Media Pembelajaran. Bandung: CV Wacana Prima. 
Tim DPAK Dikti. 2003. Pedoman Penjaminan Mutu (Quality Assurance) Pendidikan Tinggi.Buku I tentang Pengertian Umum. Jakarta. Direktorat

Tim DPAK Dikti. 2003. Pedoman Penjaminan Mutu (Quality Assurance) Pendidikan Tinggi.Buku II tentang Kurikulum Program Studi. Jakarta. Direktorat Pembinaan Akademik dan Kemahasiswaan. Direktorat Jenderal Pendidikan Tinggi Departemen Pendidikan Nasional

Widodo, C. dan Jasmadi. 2008. Buku Panduan Menyusun Bahan Ajar. Jakarta: Elex Media Komputindo. 